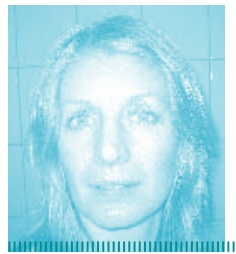

Lone Hansen, sykepleier, Bodø legevakt og overgrepsmottaket iBodø.
Ole Greger Lillevik, førstelektor, og studieansvarlig for videre-utdanning om vold i nære relasjoner, Høgskolen i Narvik.

\section{Anne Mette Finsrud,}

anestesisykepleier,

Bodø legevakt og

overgrepsmottaket

¡Bodø.

\title{
Når kvinner blir hos menn som slår
}

\author{
Grunnene til at kvinner blir værende i forhold med menn som slår dem, er mange og sammensatte.
}

V i er to sykepleiere som jobber ved et overgrepsmottak for seksuelle overgrep og vold i nære relasjoner. Vold i nære relasjoner er et tema som er mye oppe i media for tiden. Alt fra slag og trusler til drap brettes ut over forsidene på de største avisene.

\begin{abstract}
Videreutdanning
Vi har tatt et årsstudium i vold i nære relasjoner og aggresjonsproblematikk ved Høgskolen i Narvik. Studiet har inspirert oss til å skrive en artikkel, som kan belyse hvorfor kvinner blir i voldelige forhold. Studieansvarlig for videreutdanningen har deltatt i skriveprosessen. Vi har intervjuet to personer som på ulike måter jobber med voldsutsatte. Den ene er ansatt på krisesenter og den andre jobber ved et overgrepsmottak. Vi valgte denne framgangsmåten fordi vi ville høre mer om informantenes meninger, erfaringer og følelser rundt temaet (1). I tillegg presenterer vi vår egen erfaring ved hjelp av en fortelling. Fortellingen er konstruert ut fra ulike praksiserfaringer, og representerer en praksis vi kan oppleve ved overgrepsmottaket.
\end{abstract}

\section{Hovedbudskap}

Artikkelen tar opp et tema som er tabubelagt i samfunnet vårt. Det er mange flere kvinner i voldelige forhold enn det man er klar over, og enn det som er dokumentert på overgrepsmottak. Åpenhet om vold i nære relasjoner, vil kanskje kunne bekjempe det $ø$ kende problemet.

\section{Søkeord}

Les mer og finn litteraturhenvisninger på våre nettsider. , Vold | Voldtekt | Kvinne / Krise
Ida

Telefonen ringer. Jeg kaster et blikk på klokka, den er 04.20. Det er fra jobb, jeg har vakt på overgrepsmottaket. Sykepleieren $i$ andre enden forteller meg at Ida er kommet. Å nei, ikke Ida igjen ... «Det er ille», sier kollegaen min. Jeg står opp i en fart. Det er bare en måned siden sist hun var hos oss. Ida kommer fra et hjem der hun var vitne til at far slo mor. Den første volden Ida husker er fra hun var fem år. Hun lå $i$ sengen sin og hørte på at far kalte mor stygge ting etterfulgt av gråtkvalte rop. Dagen etter lurte Ida på hvorfor mor gikk med solbriller? Det var jo ikke sol ute. Mor sa hun hadde vondt i øynene og Ida slo seg til ro med det. Etter hvert skjønte Ida mer og mer. Mor ble jevnlig utsatt for vold av faren. Senere ble Ida også direkte utsatt for vold $i$ hjemmet.

\section{Redd}

På vei mot overgrepsmottaket er jeg forvirret av følelsene mine. Jeg er både glad, trist og redd. Glad for at Ida faktisk kommer til oss, at hun stoler på oss. Trist for at en slik flott kvinne må gjennomgå denne volden hjemme, og for at hun nå må gå gjennom alt sammen med oss igjen. Hun må forklare alt i detalj, og oppleve smerten på nytt. Ida må kle av seg, ikke bare psykisk, men også fysisk, for å ta bilder av alle blåmerker på den tynne, spede kroppen. Men mest av alt er jeg redd. Redd for hvor ille skadene hennes er nå. Redd for at hun ikke skal anmelde mannen sin denne gangen heller. Redd for at hun skal dra tilbake til ham og aldri komme tilbake.

\section{Vold i media}

Man ser vold relativt ofte i media. I 2006 var det 30 drap i Norge, ti av disse var kvinner drept av sine nåværende eller tidligere partnere (2). Det er vanskelig å forstå at noen kan drepe den man er mest glad i. Det er da nærliggende å tro at mannen er utilregnelig, men det behøver ikke være tilfelle.
Familiesituasjonen kan være det stedet hvor de sterkeste følelsesmessige opplevelsene utspiller seg, og da utløses også de sterkeste reaksjonene. Å søke hjelp er vanskelig. Kvinnen er kanskje ikke klar til å snakke, eller erkjenne at hun lever i en voldelig relasjon.

\section{Sjalusi}

Den dagen Ida giftet seg med Fredrik og var den lykkeligste dagen i livet hennes. Lykken varte ikke lenge. Det første møtet Ida hadde med volden i dette forholdet var etter ett år. Fredrik ble sjalu da Ida snakket med en kollega ute på byen. Da de kom hjem begynte de å krangle. Skjellsordene haglet og han slo henne. Ida hadde da tidligere sett tendenser til sjalusi, men trodde aldri Fredrik skulle gå så langt.

\section{Usynlig}

I alle voldssaker på vår arbeidsplass har det også foregått psykisk vold. Dette er den mest utbredte formen for vold. Den er usynlig og vanskelig å definere. Volden er godt kamuflert, men kvinnen vet når og hvor den skjer. Andre kan gjerne oppleve overgriperen som snill og omtenksom. Han kan være hjelpsom og elskverdig utad. Denne formen for vold kan gå så langt at offeret blir isolert fra omverdenen. Hun kutter kanskje ut kontakten med familie og venner på grunn av skam eller redsel (3). Det å føle seg alene i verden, uten noen å stole på, er skremmende. Mannen er kanskje den eneste kvinnen har. Vi har vel alle opplevd at forelskelse gjør blind. Graden av vold som blir bortforklart er selvfølgelig vesentlig. Kvinnen har et ønske om at dette bare er et engangstilfelle. Hun elsker mannen sin, men vil ha slutt på volden. Det å ha vært utsatt for vold som barn, gjør at kvinnene leter etter noe kjent fra barndommen hos mannen. Selv vold som kan være farlig, er trygt for henne. 


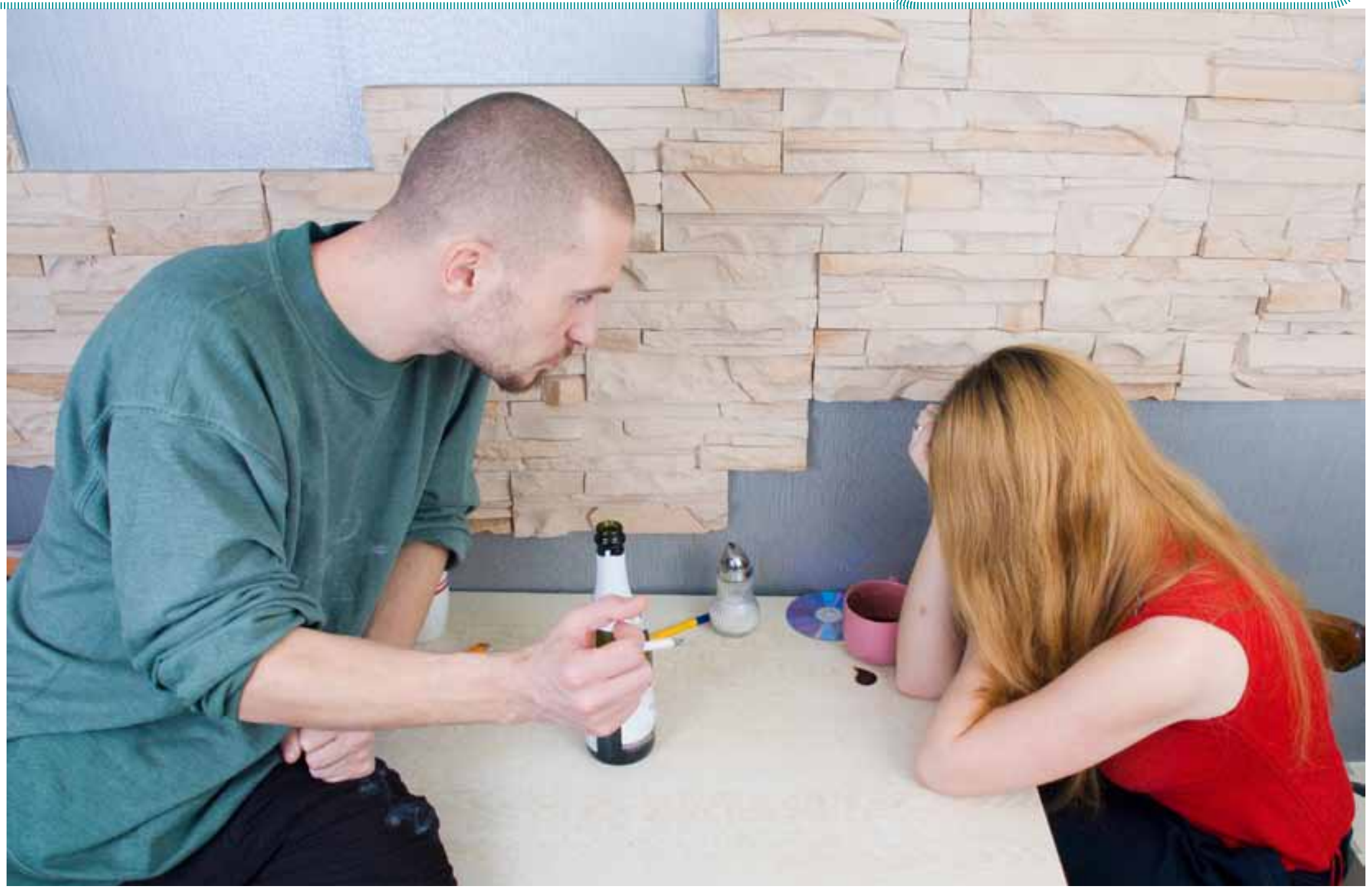

VOLD I HJEMMET: Kvinner som lever med voldelige menn trenger ofte mye støtte og lang tid for å bryte ut av forholdet. Illustrasjonsfoto: Colourbox.

\section{Venter}

Da jeg kommer på jobb snakker jeg først med kollegaen min. Ida kom direkte hit, meldte seg i luka, og sa hun hadde blitt utsatt for vold. Hun sitter nå på et eget rom og venter på oss. Det er kamera på rommet der hun er. Jeg ser henne på skjermen. Hun rister, jeg rister. Hun gråter, jeg gråter inni meg. Jeg går inn til henne.

\section{Mottaket}

På overgrepsmottaket tar vi imot kvinner rett etter det siste overgrepet har skjedd. Utover samtale, medisinsk ivaretakelse og skadedokumentasjon, har vi ingen lovpålagt oppfølging. Tilbudet er gratis og krever ingen anmeldelse. Overgrepsmottak dokumenterer fysisk vold veldig nøye. Hvis noen av disse sakene kommer til rettssystemet er det veldig viktig for offerets sak at absolutt alt av skader er beskrevet. Vi oppbevarer klær som bevismateriale i 3 måneder, slik at offeret kan velge å anmelde overgrepet i ettertid. Rapport og bilder blir arkivert. Når kvinnene har valgt å uttale seg til politiet i forkant av ankomst på overgrepsmottaket, kan vi oppleve dem som slitne. Kvinnen vil da bare ha vår dokumentasjon av de fysiske skadene overstått. Dette kan gjøre arbeidet vårt med den gode samtalen vanskelig. Kvinnen ønsker å dra hjem igjen fortest mulig. De fleste av disse kvinnene sier at det er trygt å dra hjem igjen. Dette underbygger teorien om den vonde sirkelen, der det etter en voldsepisode nesten ikke finnes grenser for hvor snill og hyggelig mannen er (4).

\section{Anger}

Etter episoder med vold, angret Fredrik noe forferdelig. Han overøste Ida med oppmerksomhet, kjwerlighet og gaver. Etter volden var Ida og Fredrik alltid veldig lykkelige. Fredrik var plutselig den mannen Ida ble forelsket $i$, giftet seg med, og ville ha barn med. Han ble den mannen ingen andre kjente. Han ble mannen i Idas liv.

\section{Mørketall}

Mange kvinner velger å ikke anmelde volden. De er redde for ikke å bli trodd. Dette føler kvinnene vil føre til retraumatisering. Det å snakke om overgrepene sine kan være som å oppleve dem på nytt (5). På overgrepsmottaket vårt ble godt under 50 prosent av voldssakene anmeldt i 2010. Informanten vår fra krisesenteret sier at de fleste kvinnene der kommer ikke til oss. Dette kan tyde på store mørketall når det gjelder vold. Begge informantene sier at de fleste tårer som blir grått er av kjærlighetssorg. Kvinnene har tross alt opplevd flest gode ting med mannen sin. Vi sier ofte at vi må se på kvinnen som mer enn et offer, hun kan være mor, søster, datter og kollega. Dette er også tilfelle for mannen. Han er mer enn en voldsmann. Han kan være far, sønn, kompis eller jaktkamerat. Dette ser og vet kvinnen.

\section{Ond sirkel}

Gjentatte voldsepisoder fører inn i en ond sirkel. Det starter med at den aktuelle situasjonen oppstår. Negative tanker og sårbarhet fører til kroppslige symptomer som for eksempel indre uro hos

\section{«Tanken på et liv i ensomhet er mer smertefull enn et liv med vold.»»}

mannen. Disse tankene og følelsene fører videre til en voldsepisode. Like etter disse episodene er det vanlig at mannen angrer dypt. Dette fører paret inn i en svært lykkelig periode. Hun modererer sine leveregler for ikke å trigge mannen til en ny voldsepisode. Etter en tid uten vold føler kvinnen at det bygger seg opp dårlig stemning igjen. Hun kan da med vilje provosere mannen. 
Hun at det vil resultere i en ny voldsepisode som igjen vil føre dem inn i den vonde sirkelen. Dette er en ubevisst handling fra kvinnens side, for å ha en følelse av kontroll. Volden blir da betimelig. Hun føler det er bedre å vite når volden kommer enn å gå og vente i redsel (4).

\section{Blodig}

Idas ansikt er fullt av tårer. Under tårene er hun rød og blodig. Hun er rød på og rundt begge øynene, de kommer til å bli blå om noen dager. Hun blør fra et kutt i leppa. Stadig slikker hun seg rundt munnen og svelger. Blod, rødt og ekte, et bevis på volden, en smak av vold. Legen snakker lenge med Ida. Fredrik var sint på grunn av en filleting, noe med søpla tror Ida. Han kalte henne hore, og slengte henne i veggen. Ida prøvde å forklare, men ingenting av det hun sa gikk inn. Han slo henne flere ganger, hun falt på gulvet, han sparket og spyttet. Han var ikke lenger hennes Fredrik.

\section{Trusler}

For å søke hjelp må kvinnen være klar til å erkjenne at det har skjedd et overgrep, og kunne fortelle om det. Dette er en dørstokkmil for kvinnene, som er blitt krenket og undertrykket over tid. Kvinnen kan få trusler fra mannen om at dersom hun går, vil han oppsøke henne, og at hun da skal få gjennomgå. Han skal kanskje ta fra henne barna, eller hun skal aldri få se dem av ulike årsaker. Som følge av disse truslene kan hun bli handlingslammet, og frykten for at volden skal bli verre kan være en av grunnene til at hun blir i relasjonen. Etter vi er ferdige med å ta bilder setter vi oss for å ta en siste prat for denne gang. Ida er sliten. Hun vil ikke bo alene, hun klarer seg ikke. Hun har ikke jobb, Fredrik har tatt mer og mer styring $\mathrm{i}$ livet hennes. Hun har ikke penger. Hun har få venner, og ingen hun føler hun kan stole 100 prosent på. Hun kommer aldri til å finne en ny mann, ingen vil jo ha henne!

\section{Typer vold}

Til overgrepsmottaket kommer kvinner som er blitt utsatt for flere typer vold. Det er sammensatte historier som ofte er gjennomsyret av krenkelser, avmakt, nedverdigelse og følelsen av ikke å være verdt noe. Disse følelsene er alle med på å gjøre at kvinnen vil hjem til det «normale» livet, selv om dette livet er fylt at kaos. Det er i det minste forutsigbart og kjent. Noen av kvinnene som kommer til overgrepsmottaket er av utenlandsk opprinnelse. Disse kvinnene har et annet syn på vold. Grunnen til dette kan være de tradisjonelle kjønnsrollene. I deres kultur er det mer aksept for vold i nære relasjoner (5). For kvinner med mi- noritetsbakgrunn er det ofte enda vanskeligere å bryte ut av et voldelig forhold enn det er for etnisk norske kvinner.

\section{Uten nettverk}

Det å bli stående helt alene uten noe nettverk rundt seg, er også en grunn til at noen kvinner velger å gå tilbake til sin voldelige mann. Tanken på et liv i ensomhet er mer smertefull enn et liv med vold. Informanten vår sa at kvinner med minoritetsbakgrunn som kommer til krisesenteret har mer komplekse og akutte problemer. De trenger hjelp til det aller meste fra sted å bo til utfylling av papirer. De etnisk norske som kommer har mer behov for et dagtilbud. Dette må man tenke på når man leser statistikk over hvem som kommer til krisesenter. Det betyr altså at det ikke nødvendigvis er mer vold i ikke-etniske norske parforhold. «Det er lett å si at det er mulig å dra fra mannen sin. Men det er ikke så enkelt å få leid en leilighet hvis man har fem barn og heter Mohammad til etternavn», sier informanten vår fra krisesenteret. Usikkerhet på hvordan hun skal greie seg økonomisk kan spille en stor rolle. Flere av kvinnene har kanskje ikke utdanning. De er avhengig av mannens økonomi.

\section{Blir verre}

Id a vet at forholdet til Fredrik ikke er bra for henne. Hun ser selv at volden blir verre og verre for hver gang. Hun prøver å gjøre Fredrik til lags hele tiden, men han finner alltid et påskudd til å bli voldelig.

\section{Barna}

Barn er nok den største grunnen til at kvinnen blir i relasjonen. Hun vil barna skal leve i en hel familie. Frykten for at de må bytte skole og eventuelt flytte fra hjemmet, kan være vanskelig å takle. Redselen for å høre barna si «Mamma, det er din feil». Redselen for å miste barna, skade dem eller på annen måte gjøre dem urett er alltid til stede. De fleste mødre gjør alt for sine barn, også det å holde ut i en voldelig relasjon. Med barn følger et livslangt samarbeid mellom foreldre. Ved å gå fra barnefaren må hun likevel forholde seg til ham gjennom barna. Det kan oppleves mer forutsigbart å bli i relasjonen slik at hun har mer kontroll over hva som skjer i forholdet mellom far og barn (6). Informanten på krisesenteret støtter opp om denne teorien. Det blir ofte sagt at nå er det snart jul, og vi kan ikke ødelegge jula for barna. Det er stadig nye begivenheter som skyver problemene framover.

\section{Hjem igjen}

Vi avslutter samtalen. Jeg spør om Ida trenger hjelp til å vcere trygg i natt. Hun skal ta inn på hotell. Ida skal dra til politiet i morgen. «Nå er det nok» sier hun. Jeg tør nesten ikke håpe, vil egentlig få henne til politiet nå med en gang. Jeg vet at jo lengre tid det går før hun anmelder, desto mindre sjanse er det for at hun gjør det $i$ det hele tatt. Ida takker for hjelpen, jeg vet hun er oppriktig takknemlig. Hun går ut gjennom døra, tar opp telefonen, og ringer på tur ned trappa. Jeg ser ut vinduet. Vil sjekke at Ida kommer seg trygt av sted. En mørk blå bil kommer kjørende etter ti minutter. En høy mann med lyst hår kommer ut av bilen. Han åpner døra på passasjersiden. Ida kommer ut fra mottaket. Hun setter seg inn i bilen. Jeg ser at de klemmer og kysser hverandre. Jeg slipper ut pusten, tror jeg har holdt den siden Ida gikk ut av døra. Jeg er tom inni meg.

\section{Avslutning}

Grunnen til at kvinner blir hos sine voldelige menn er mange. Hensynet til barna er nok en av de største grunnene (6). Kjærligheten som kvinnen likevel har til mannen sin er en annen grunn (6). Et vanlig spørsmål er: «Hvorfor går du ikke?». Men hva om vi i stedet spør om hvorfor ikke mannen tar ansvar for situasjonen og drar hvis han er så misfornøyd med relasjonen at han må bruke vold? (7). Både vi og vår informant fra overgrepsmottaket har sett at vi kanskje fokuserer for mye på fysisk vold og synlige skader. Dette er selvfølgelig viktig hvis saken går til retten, men det aner oss at disse kvinnene egentlig trenger noe annet og mer. Kvinnene skal leve videre etter bruddet, og trenger kontakt med andre instanser for videre hjelp og støtte. Informasjon og styrking av selvfølelse er noe vi kan legge mye mer vekt på. Dette kan hjelpe kvinnen ut av den voldelige relasjonen. Hvis hun ikke ønsker seg ut av forholdet er det mulig å henvise mannen til videre sinnemestring. Dette kan gjøre at både mannen og kvinnen făr det bedre. Vi har innsett at det er en lang prosess for en kvinne å komme ut av et voldelig forhold. Prosessen for et bedre liv, kan starte hos oss. Vi kan bare hjelpe dem et steg videre på veien. IIII

\footnotetext{
LITTERATUR

Pettersen RC. Oppgaveskrivingens ABC. Oslo: Universitetsforlaget, 2008. http://nhi.no/forside/vold-mot-kvinner-35908.html.

Isdal P. Meningen med volden. Oslo: Kommuneforlaget, 2000

Møller M. I fars vold. Oslo: Kommuneforlaget, 2000.

Kirkengen AL. Hvordan krenkete barn blir syke voksne. Oslo: Universitetsforlaget, 2005.

Pettersen, BW. I privatlivets vold. Oslo: Aschehoug, 1997. Råkil M. Menns vold mot kvinner. Oslo: Universitetsforlaget, 2002.
} 